Ann. Biol. anim. Bioch. Biophys., 1978, 18 (4), 857-861.

\title{
Immunohistochemical cross-reaction of anti-mammalian LH-RH in lower vertebrates
}

\author{
par H. J. Th. GOOS, P. G. W. J. VAN OORDT \\ Zoological Laboratory, Section Comparative Endocrinology \\ Pauduala an 8, Utrecht, The Netherlands.
}

Summary. The double antibody immunofluorescence method has been applied to demonstrate LH-RH in several amphibian and teleost species. In all amphibians tested, perikarya and axons running towards the median eminence could be visualized using antimammalian-LH-RH. In the teleost species investigated so far, only the trout Salmo gairdneri showed a positive reaction. It is argued that this is caused by lack of cross-reactivity in the other species rather than by insufficient sensitivity of the method.

\section{Introduction.}

In fish and amphibians the gonadotropic function of the pituitary is controlled by the hypothalamus. In teleosts this hypothesis is mainly based on observations of correlative changes in environmental factors, hypothalamic nuclei and adenohypophysial activity (Peter, 1970 ; Ball et al., 1972). In addition, neurosecretory fibres, originating from the hypothalamus, are known to terminate on glandular cells of the adenohypophysis, on neighbouring capillaries, and on membranes of intracellular spaces (Zambrano, 1972 ; Peute ef al., 1976). These observations and the results of lesioning experiments (Peter, 1970) focussed attention on the nucleis lateralis fuberis (NLT) as the source of a gonadotropin releasing hormone (GRH) in teleosts. Similar results were obtained with amphibians. By isolating the ventro-caudal region and the adjacent pituitary from the rest of the hypothalamus in Rana temporaria, Dierickx (1966, 1967) proved that the ventral tuber cinerium hypothalami is involved in the central regulation of the pituitary. That area contains the peptidergic, Gomori-negative nucleus infundibularis ventralis (NIV). In Rana esculenta, it is one of the cell types in this nucleus which after castration or testosterone treatment shows correlative changes with the gonadotropic activity of the adenohypophysis (Peute and Mey, 1973). Consequently, this cell type may produce GRH. Definite conclusions about the cellular origin of GRH cannot be drawn until this hormone is demonstrated directly within the perikarya and in the axons ending in the neurohypophysis. For this purpose immunohistochemical methods can be applied, provided that pure antigen is available.

Amphibian and fish GRH has not been isolated and purified yet. The only GRH available at present is mammalian LH-RH. A number of experimental data indicate 
that mammalian LH-RH is biologically active in amphibians and fish. Some of the results (see discussion) already make it doubtful that mammalian LH-RH is identical to the GRH of lower vertebrates ; this is supported by the results of radioimmunoassay of fish hypothalamic extracts and by the present results.

The aim of the present study was to ascertain whether antimammalian LH-RH shows histo-immunological cross-reaction with material in the brain of amphibian and teleosts species.

\section{Material and methods.}

Experimental animals. - Sexually mature specimens have been used.

Amphibians : male and female green frogs (Rana esculenta). We examined no other amphibians, but compared our results with published information on other anurans.

Teleosts : male and female trout (Salmo gairdneri) ; barbels (Barbus conchonius) ; head-and-tail-lights (Hemmigrammus caudovitatis) and the goldfish (Carassius auratus).

Preparation of the tissues. - All tissues were fixed in buffered Bouin's fluid without acetic acid.

Antibodies. - Antibodies were raised against synthetic LH-RH (Bochem-California) conjugated to bovine serum albumine according to the method of Jeffcoate ef al. (1973). The presence of antibodies against LH-RH was tested by means of radioimmunoassay and agar diffusion.

Immunofluorescence. - The double antibody technique was used, the first antibody being the anti-LH-RH preparation, the second a commercial sheep anti-rabbit globulin, labelled with FITC (NBC or Nordick). If unspecific fluorescence was observed, both the first and the second antiserum were treated with liver homogenates from the species tested to avoid further unspecific binding of antibody to non-LH-RH tissue components.

For a more detailed description of material and methods, see Goos et al. (1976) and Goos and Murathanoglu (1977).

\section{Observations.}

In Rana esculenta, perikarya reacting with anti-LH-RH were found in an unpaired nucleus, sifuated immediatly in front of the preoptic recess. Axons from these cells form a narrow single tract, which passes underneath the preoptic recess. Behind the recess the tract divides into two bundles running between the preoptic nucleus and the optic chiasma, in a caudal direction. Just before entering the median eminence this tract splits up into numerous individual fibres apparently ending near the capillaries in the outer zone (Goos ef al., 1976). In Hemigrammus caudovitatus, Barbus conchonius and Carassius auratus no positive reaction has been observed until now in any part of the brain. In Salmo gairdneri, however, numerous immunoreactive fibres are running diffusely in the lateral walls of the diencephalon and ending dorsally of the pituitary 
stalk. Small oval or round perikarya with immunoreactive cyloplasm and a protrusion, which is apparently the beginning of an axon, were found in the area dorsalis partis medialis of the telencephalon (Goos and Murathanoglu, 1977).

\section{Discussion.}

Mammalian LH-RH is known to be biologically active in a number of fish species. Deery (1973) and Deery and Jones (1975) proved that synthetic LH-RH causes an activation of the adenylcyclate system in the gonadotropin-containing ventral lobe of the pituitary of the dogfish, Scyliorhinus canicula. Gonadotropin secretion was obtained in the carp, Cyprinus carpio (Breton and Weil, 1973) and in the brown trout, Salmo trutta (Crim and Cluett, 1974) ; ovulation was induced in the ayu, Plecoglossus altivelis (Hirose and Ishida, 1974) and in the goldfish, Carassius auratus (Lam et al., 1975) ; depletion of small electron-dense granules from the gonadotropic cells, together with ovulation was reported by Lam ef al. (1976) for the goldfish.

There are, however, several arguments for considering teleost GRH to be different from mammalian LH-RH. Breton and Weil (1973) found that carp hypothalamic extract stimulates gonadotropin secretion in the carp with a different time sequence, when compared to synthetic LH-RH. Extracts of the hypothalamus of the goldfish did not appear to have any immunological cross-reaction with synthetic LH-RH when tested by radioimmunoassay (Deery, 1974).

The present results show that from the fish tested only the trout, Salmo gairdneri, has a substance that is immunoreactive with antimammalian LH-RH. It might be possible that the other species indeed contain this substance but in minute amounts; the failure to demonstrate it than could due to lack of sufficient sensitivity of the applied method. However, since not a single immunoreactive axon, nerve ending or perikaryon has been observed this failure is more likely caused by lack of immunological cross-reaction. On the other hand, it can not be excluded that if these teleost species had been checked during different phases of their reproductive cycle, or after castration or hypophysectomy, more positive results could have been obtained.

In the frog, Rana pipiens, mammalian LH-RH has been demonstrated to be biologically active (Thornton and Geschwind, 1974). In all species tested so far, antimammalian LH-RH has an immunological binding to perikarya, axons and nerve endings in the forebrain and neurohypophysis. This applies to Rana pipiens and Rana catesbiana (Alpert et al., 1976); Xenopus laevis (Doerr-Schott and Dubois, 1976); Bufo vulgaris (Doerr-Schott and Dubois, 1975) ; Rana esculenta (Goos ef al., 1976). Moreover, Deery (1974) demonstrated that in radioimmunoassay with anti-mammalian LH-RH, hypothalamic extracts of Xenopus laevis did have an immunological binding.

The available information indicates that a GRH-like system must be present in lower vertebrates, i. e. fish and amphibians. There is no conclusive evidence for mammalian LH-RH being similar to such a substance in lower vertebrates, but amphibian $\mathrm{GRH}$ seems to have a closer resemblance to mammalian LH-RH than to the corresponding hormone in fish. Given the many failures in demonstrating GRH in fish by using anti-mammalian LH-RH, it is obvious that isolation, purification and synthe- 
tizing of fish GRH is a prerequisite for studying the hypothalamic regulation of GTH production in these vertebrates.

Symposium sur la Reproduction des Poissons Paimpont, France, 19-21 septembre 1977.

Résumé. La technique d'immunofluorescence par double anticorps a été utilisée pour mettre en évidence la LH-RH dans plusieurs espèces d'Amphibiens et de Téléostéens. Chez les Amphibiens étudiés, les périkaryons et les axones allant vers l'éminence médiane peuvent être visualisés en utilisant un anti LH-RH mammalien. Parmi les Téléostéens étudiés, seule la Truite Salmo gairdneri a montré une réaction positive. II est probable que ce n'est pas la sensibilité de la méthode qui est en cause, mais l'absence d'immunoréactivité vis-à-vis de l'anti LH-RH des facteurs hypothalamiques des autres espèces étudiées, d'origine mammalienne.

\section{References}

ALPERT L. C., BROUWER J. M., JACKSON J. M. O., REICHHIN S., 1976. Localisation of LH-RH in neurons in frog brain (Rana pipiens and Rana catesbiana). Endocrinology, 98, 910-922.

BALL J. N., BAKER B. I., OLIVEREAU M., PETER R. E., 1972. Investigations on hypothalamic control of adenohypophysial functions in teleost fishes. Gen. comp. Endocr., suppl. 3, 11-21.

BRETON B., WEIL C., 1973. Effects du LH/FSH-RH synthétique et d'extraits hypothalamiques de carpe sur la sécrétion d'hormone gonadotropin in vivo chez la carpe (Cyprinus carpio L.). C. $R$. Acad. Sci. Paris, Sér. D, 277, 2061-2064.

CRIM L. W., CLUETT D. J., 1974, Elevation of plasma gonadotropin concentration in response to mammalian gonadotropin releasing hormone (GRH) treatment in the male brown trout as determined by radioimmunoassay. Endocr. Res. Comm., 1, 101-110.

DEERY D. J., 1973. Activation of dogfish adenyl cyclase : effects of hypothalamus extracts and synthetic LH-RH. Int. Res. Comm. Syst. (73-5) 3-5-7.

DEERY D. J., 1974. Determination by radioimmunoassay of the luteinizing hormone releasing hormone (LH-RH) content of the hypothalamus of the rat and some lower vertebrates. Gen. comp. Endocr., 24, 280-285.

DEERY D. J., JONES A. C., 1975. Effects of hypothalamic extracts neurotransmitters and synthetic hypothalamic releasing hormones on adenyl cyclase activity in the ventral lobes of the pituitary of the dogfish (Scyliorhinus canicula). J. Endocr., 64, 49-57.

DIERICKX K., 1966. Experimental identification of a hypothalamic gonadotropic centre. Z. Zellforsch., 74, 53-79.

DIERICKX K., 1967. The function of the hypophysis without preoptic neurosecretory control. Z. Zellforsch., 78, 114-130.

DOERR-SCHOTT J., DUBOIS M. P., 1975. Localisation et identification d'un centre LH-RF dans l'encéphale du crapaud, Bufo vulgaris Laur. C. R. Acad. Sci. Paris, Sér. D, 280, 1285-1287.

DOERR-SCHOTT J., DUBOIS M. P., 1976. LH-RH-like system in the brain of Xenopus laevis Daud. Immunohistochemical identification. Cell Tissue Res., 172, 477-486.

GOOS H. J. Th., LIGTENBERG P. I. M., OORDT P. G. W. J. van, 1976 . Immunofluorescence studies on gonadotropin releasing hormone (GRH) in the forebrain and the neurohypophysis of the green frog Rana esculenta. Cell Tissue Res., 168, 325-333.

GOOS H. J. Th., MURATHANOGLU O., 1977. Localisation of gonadotropin releasing hormone $(\mathrm{GRH})$ in the forebrain and neurohypophysis of the trout (Salmo gairdneri). Cell Tissue Res., 181, 163-168.

HIROSE K., ISHIDA R., 1974. Induction of ovulation in the ayu, Plecoglossus altivelis with LH-releasing hormone (LH-RH). Bull. jap. Soc. Sci. Fish., 40, 1235-1240.

JEFFCOATE S. L., FRASER H., GUNN A., HOLLAND D. T., 1973. Radioimmunoassay of luteinizing hormone releasing factor. J. Endocr., 57, 189-190.

LAM T. J., PANDEY S., HOAR W. S., 1975. Induction of ovulation in goldfish by synthefic luteinizing hormone-releasing hormone (LH-RH). Canad. J. Zool., 53, 1189-1192. 
LAM T. J., PANDEY S., NAGAHAMA Y., HOAR W. S., 1976. Effect of synthetic luteinizing hormonereleasing hormone (LH-RH) on ovulation and pifuitary cytology in the goldfish Corassius auratus. Canad. J. Zool., 54, 816-824.

PETER R. E., 1970. Hypothalamic control of thyroid gland activity and gonadol activity in the goldfish, Carassius auratus. Gen. comp. Endocr., 14, 334-356.

PEUTE J., MEY J. C. A., 1973. Ultrastructural and functional aspects of the nucleus infundibularis ventralis in the green fog, Rana esculenta. Z. Zellforsch., 144, 191-217.

PEUTE J., BRUYN M. G. A. de, SELDENRIJK R., OORDT P. G. W. J. van, 1976. Cytology and identification of gonadotropic cells in the pituitary of the black molly (Poecilia lafipinna) ; an electron microscopical study. Cell Tissue Res., 174, 35-54.

THORNTON V. F., GESCHWIND I. I., 1974. Hypothalamic control of gonadotropin release in amphibia : evidence from studies of gonadotropin release in vitro and in vivo Gen. comp. Endocr., 23, 294-301.

ZAMBRANO D., 1972. Innervation of the teleost pituitary. Gen. comp. Endocr., suppl, 3, 22-31. 